\title{
Influence of Selected Instructional Factors on Pupils Competency Skills in Keiyo South Sub County, Kenya
}

\author{
Aniter J. Kibet \\ Faculty of Education and Community Studies, Egerton University, Kenya, P.O. Box 536-20115 Njoro, Kenya
}

\begin{abstract}
The purpose of this study was to investigate teachers' perceptions on the influence of selected instructional factors on pupils' acquisition of competency skills in pre-school centres in Keiyo South Sub County in Elgeyo-Marakwet County. This study was guided by Piaget cognitive development and functionalism theory of learning. The research design for the study was descriptive survey. The target population for the study comprises of all 60 pre-primary schools in the Sub County with a total of 144 preschool teachers. The results of the study showed that the selected school instructional factors affected learners' acquisition of competency skills in numeracy, literacy and oral skills. The teachers perceived that instructional factors were significant to pre-school children acquisition of competencies. The study recommends that pre-school centres should be adequately equipped with instructional resources, teachers to undergo in-service training. The study findings are of significance to the schools and government towards improving the status of early childhood education.
\end{abstract}

Keywords: learning resources, perceptions, competency skills and instructional factors

\section{Introduction}

Early childhood is a crucial stage of life in terms of a child's physical, intellectual, emotional and social development (Du Plessis \& Naude, 2003). Education and care of young children is of crucial importance for their development (O'Connor \& Geiger, 2009). It ensures that children grow up into strong and healthy adults mentally, physically, emotionally and intellectually (United Nations Education Scientific \& Cultural Organisation [UNESCO], 2007). Psychologists generally agree that the period below five years is critical in the development of a human being (Kamau, 2010). Studies from the several nations across world, demonstrates that pre-school education has multiple effects on child development (Blakemore \& Frith 2005; Shonkoff \& Phillips 2000; Sylva \& Pugh 2005). These benefits are thought to include the development of higherorder cognitive skills such as problem solving and thinking and improved social adjustment and family functioning (Ou \& Reynolds 2004; UNESCO, 2007). In Kenya, the program is largely constitutive of the developmental experiences of young children zero to six years and has primarily focused on the custodial care and cognitive development of children in preparation for formal schooling (Ngaruiya, 2004). The government of Kenya has endeavoured to implement a holistic Early Childhood Development (ECD) program for children zero to eight years to fulfil its commitment to the recommendations of the Jomtien World Conference on Education For All (EFA) and the 2001 Dakar Framework for Action. This is achieved through ensuring pre-school learners develop competencies in reading, counting, and ability to write correctly specified words and names. Development of competency skills for pre-school children is important to academic achievement (Washington, 2001). Literacy is fundamental to all areas of learning as it unlocks access to the wider curriculum. Being literate increases opportunities for the learner in all aspects of life, lays the foundations for lifelong learning and work, and contributes strongly to the development of all four capacities of curriculum for excellence (Bunyi, Wangia, Magoma \& Limboro, 2011). Mweru (n.d) observes that a greater number of young children are being enrolled for preschool education and are therefore spending a great percent of their childhood years under the care of preschool teachers. The teachers act as role models and tend to pass on the attitudes and views they hold to children. They therefore play a major role in the preschool children's lives and any prejudices they hold can, when communicated to young children, leave an indelible mark in young children's minds. Considering the various perspectives explaining learning amongst children, this study determined how selected instructional factors; availability of learning resources and their appropriateness influence acquisition of numeracy and literacy competencies among pre-school children in Keiyo South Sub County. The early childhood education syllabus developed by the Kenyan Ministry of Education places an emphasis on the importance of instructional factors during learning in preschools (Kenya Institute of Education [KIE], 2008). However, Ngaruiya (2004) argues that public and private ECD models in Kenya have wide disparities not only in terms of curriculum but also in facilities and quality of services offered. Rotumoi and Too (2012) indicates that the public pre-schools in poor urban neighbourhoods are often characterized by inadequate play learning materials, shortage of trained pre-school teachers and lack of health and nutrition services. According to Ngaruiya (2004), majority of pre-schools follow a traditional teacher-centred teaching methodology with emphasis on recitation and memorization. On the other hand, most of the private pre-schools are well equipped and responsive to children's needs. Majority of the public ECD centres (pre-schools) in Kenya do not provide holistic services and are faced with numerous problems, including inadequate government support, inadequate childcare and the absence of health and nutrition services (Ngaruiya, 2004). The statistics are appalling knowing that pre-school is the foundation stage of child social-cognitive development. A study by Rotumoi and Too (2012) found out that there was a tendency by pre-school teachers to make use of other 


\section{International Journal of Science and Research (IJSR) \\ ISSN (Online): 2319-7064 \\ Index Copernicus Value (2013): 6.14 | Impact Factor (2015): 6.391}

teaching strategies which were not necessarily effective in schools and it was mostly occasioned by other factors that were prevalent in different pre-school centres. Ngaruiya (2004) asserted that pupils are admitted into primary school after attaining five or six years without any consideration for their readiness to learn. This forced majority of pupils to drop out of primary school while others repeated nursery school. From the studies reviewed, it is clear that competency skills that involve numeracy, literacy and reading cannot be without provision of instructional resources, competent and qualified teachers and improving teacher workload and responsibilities in pre-school centres. Competency skills in reading, writing and numeracy among pre-school pupils in public schools in Kenya have been noted to be generally low and Keiyo South is not an exception. Various factors have been noted to be contributing to poor competency skills among pre-school children. It is due to these factors that this study investigated preschool teachers' perceptions on the influence of selected instructional factors on acquisition of competency skills by learners in pre-school centres in Keiyo South Sub County.

\section{Review of Related Literature}

\section{Influence of Learning Resources on Pupils' Competency Skills}

Learning resources include textbooks, charts, maps, audiovisual and electronic instructional materials such as radio, tape recorder, television and video tape recorder (Likoko, Mutsotso \& Nasongo, 2013). Other category of material resources consist of paper supplies and writing materials such as pens, eraser, exercise books, crayon, chalk, drawing books, notebooks, pencil, ruler, slate, workbooks and so on (Atkinson 2000). Gogo (2006) suggests that in order to provide quality pre-school education the availability of relevant teaching learning materials and facilities is crucial. For teachers to use learning resources in their teaching, the materials should be made available. Teaching materials can be substituted, they can be improvised and still deliver the same message (Kadzera, 2006). Therefore in preschool centres, children should be encouraged to do independent reading and writing. In planning all such activities, teachers should use their knowledge of the stages of development in oral language, reading, and writing (UNESCO, 2005). Schools should also provide children with appropriate materials when they are to be engaged in free exploration, focused exploration, and guided activities (O'Connor \& Geiger, 2009). Preschool programs should provide opportunities for children to listen to poems, stories, and non-fiction texts for both enjoyment and information. Children should also have opportunities to respond to a variety of materials that are read aloud to them and to demonstrate awareness of written materials, print conventions (concepts of print), and language patterns. Moreover, teachers should provide children with many opportunities to explore texts independently, to retell stories, and to internalize new learning (Gogo, 2002). Teachers can plan brief, focused, daily experiences that build on a particular concept or set of ideas. They also need to plan intentional and engaging literacy instruction during the day. They can ensure that significant literacy learning is included in play, daily routines, and classroom experiences (O’Connor \& Geiger, 2009). Teachers can also make use of drama, music, visual arts, and media texts to help children develop their communication and literacy skills. In so doing, teachers can create an effective environment to support young children's learning and development of literacy. According to National Curriculum Research (2007), play materials as a resource for pupils are considered first of all by the teachers to develop the learners socially, and a feeling of confidence as the most important learning product of play activities. Cognitive development is also enhanced by play activities; outdoor play actions are especially beneficial for motor development. Play activities among children supply them with a balance between construction play and dramatic play and play materials enhances the development of language and emotional part of the learner this helps to bridge the gap between pre-school and primary schools as the learners were used to a lot of play in pre-school classes. Play materials in classroom can help to raise the pupils' interests, curiosity and attitudes towards their learning (Johnson, Christine \& Yawkeys, 2009). Although these suggestions are commendable, they may be difficult to implement in preschools, where resources is inadequate. The study show how learning resources influence pupils' acquisition of competency skills in pre-schools. The ability of the teacher to take advantage of existing learning materials and to create others, to respond to children's needs, and to maintain enthusiasm and hope in unfavourable conditions but it is clear that the personal qualities, technical skills, and motivation of the teacher are central elements in determining the learners acquisition of competency skills (Docket \& Perry, 2001). A number of factors guide the teacher to appropriately choose prepare and use the various types of teaching aids for effectiveness (Schonwetter, 2008). These includes the teachers' knowledge and skills, the time available, the size of the class, the objectives of the lesson, the instructional methods used, the content of the lesson, and the cost of teaching / learning aids to be used. Further the quality of learning experiences will be influenced by how the teacher plans to use these teaching aids. Thus, the teacher should ensure that teaching aids appeals to as much sense as possible, are appropriate in quality, allow for practice, are learner friendly, are the right size, are appropriately used and do not obscure the focus of the lesson (Schonwetter, 2008). A study conducted in Malawi by Kadzera (2006) found out that infrequent use of higher order instructional technologies for instance, overhead projectors, videos, and computers, which was attributed to lack of training, unavailability of the technologies, and lack of maintenance. The failure to use the locally available resources by some of the tutors was attributed to lack of creative thinking as well as lack of initiative to use the local environment in their teaching. In Nigeria, Adeogun (2001) discovered a very strong positive significant relationship between instructional resources and academic performance. According to Adeogun, schools endowed with more resources performed better than schools that are less endowed. This corroborated the study by Babayomi (1999) cited in Likoko et al., (2013) established that private schools performed better than public schools because of the availability and adequacy of teaching and learning resources. Adeogun (2001) discovered a low level of instructional resources available in public schools and stated that our public schools are starved of both teaching and learning resources. He expresses that effective teaching cannot take 


\section{International Journal of Science and Research (IJSR) \\ ISSN (Online): 2319-7064 \\ Index Copernicus Value (2013): 6.14 | Impact Factor (2015): 6.391}

place within the classroom if basic instructional resources are not present. Mbugua (2011) determined the adequacy of teaching and learning resources in secondary schools as a contributing factor to achievement in mathematics. The study used ex post facto research design and an observation schedule, mathematics teachers' and students' questionnaires were used to collect the needed data. A total of 661 from three students and 71 mathematics teachers participated in the study. The findings indicate that secondary schools are poorly equipped with the teaching and learning resources for mathematics; which is serious since mathematics is an abstract subject which requires these materials to facilitate abstraction of concepts by the learners. Akungu (2014) examined the influence of teaching and learning resources on students' performance in KCSE in FDSE in Embakasi district. The study used descriptive study design, and data was collected using three sets of questionnaires for the head teachers, teachers and students. The study found out that teaching and learning materials were available and are utilized in schools, especially those used in classroom instruction, like chalks, dusters and charts except physical facilities are lacking and there's gross inadequacy of human resources. This resulted to overstretched resources with annual increase in enrolment rates thus compromising the quality of education. A study by Murundu, Chisikwa and Okwara (2010) found many deficiencies in analyzed centres, which may prevent successful implementation of pre-school curriculum and pupils' acquisition of competency skills. They cited factors including lack of required learning resources and facilities, types of learning groups that are not recommended, failure to use learners' mother tongue, understaffing and lack of balanced diet for feeding children. From the study by Murundu et al., (2010), it was concluded that teaching and learning resources in pre-school centres are inadequate in terms of both quality and quantity and sometimes teachers teach pupils without them. This may influence the acquisition of competency skills by learners in pre-school centres. Muthamia (2009) explains that teachers can only be effective and productive in their work if they have adequate and relevant facilities. Kamau (2010) research in Makuyu zone found out there was no clear cut indication whether there was or no adequate reference materials for mathematics in Early Childhood Development Education (ECDE) classes as half of them said materials while the other portion said the learning reference materials for numeracy skills were inadequate.

\section{Appropriateness of Learning Resources on Pupils Competency Skills}

The use of learning resources in the classroom has the potential to help the teacher explain new concepts clearly, resulting in better student understanding of the concepts being taught (Kadzera, 2006). In a survey, to find factors that facilitate teacher skill, teacher morale, and perceived student learning in technology-using classrooms, Baylor and Ritchie (2002) found that teachers valued the use of technologies in class and that it had an impact on students' content acquisition; the use of technology added to class performance. Barasa (2005) opines that the use of resources can be made more effective if the teacher has knowledge and skills on how to effectively utilize in the teaching-learning process. Barasa highlights the fact that the availability of teaching resources and the teachers' awareness of their utility enhance learner performance. According to Corsaro and Molinari (2005), learning resources are important in learning because they enable pupils to take active involvement in learning activity. Resources are effective tools for conveying information vividly to learners. It adds joy to class and makes learners alert to every proceeding and more attentive. Charles and Senter (2002) contended that when teachers speak of motivation as a component of a lesson, they refer to what they do to attract students' interest and engage them more or less willingly in the work provided. The instructional resources which pupils can easily manipulate to obtain a required end product can generate the desire to learn and do more. Resources that preschool learners can associate with their everyday life also help to generate that desire to do more hence leading to acquisition of relevant numeracy and literacy skills. Tietjen, Raman and Splaulding (2003) opine that in majority of sub Saharan African nations, textbooks often reach remote schools well after the beginning of the school year if they arrive at all. Less than half of the learners present in class had required text books (Lloyd, Mench \& Clerk, 2000). Availability of books in general poses a challenge to education in the poorest developing countries. More than half of all the learners in eight countries participating in the Southern and Eastern Africa Consortium for Monitoring Educational Quality (SACMEQ) sample attended school without books. Providing books in second and third languages, especially those that are tailored to the language requirements of the minority groups, is out of the question. Even when basic textbooks are available, schools in poor areas often lack other instructional materials. Study of poor district in India found that while most schools in these districts have sufficient textbooks and learning materials for students, classrooms lack supplementary materials as teacher guides, dictionaries, maps, globes and instructional kits (World Bank, 1997). Nabwire (2008) carried out a study in Kenya on the use of visual aids and suggested that visual aids introduce variety in the lesson and thus stimulate learning. The process of learning involves the activities in which pupils engage in order to make sense of or master the content they are learning. In addition, they offer manipulative or other hands-on activities for pupils who need them to facilitate learning. Mutai (2006) cited by Likoko et al., (2013) postulates the pre-school learning is strengthened when there are enough reference materials such as textbooks, stationary and teaching aids. However, Rotumoi and Too (2012) opines that there are gaps in the existing policy guidelines on promotion of early childhood development curriculum in Kenya. Rotumoi and Too (2012) argues that preschools for poor people often lack basic instructional materials. They found out that pre-school teachers were generally poorly equipped as parents did not think it was their responsibility to provide materials and equipment. The pre-school project surveys found most of the pre-schools in Kilifi were poorly furnished and equipped. This finding is supported by Njonjo's findings in Nairobi where most Harambee schools had very poor physical facilities and the blackboard was the only teaching aid available (Muthamia, 2009). Mbugua (2011) found out that poor quality of instructional materials made it difficult for the learners to see the indented relationship resulting to poor achievement in the subject. Most teachers use textbooks 


\section{International Journal of Science and Research (IJSR) \\ ISSN (Online): 2319-7064 \\ Index Copernicus Value (2013): 6.14 | Impact Factor (2015): 6.391}

when teaching, they provide many supplementary materials such as problems to solve, extra practice and for assessment Secondary school mathematics teachers are expected to be professionals by training. Data obtained shows that $98.52 \%$ of secondary school mathematics teachers are professional teachers; therefore their output is expected to be high. Mastery of the subject is an absolute necessity for effective teaching, the teacher must possess a basic qualification in the subject and the level of qualification should be much higher than that of the information he/she is expected to impact. In a study conducted in private teachers training colleges in Western Kenya, Likoko et al., (2013) established that the status of instructional materials, equipment and facilities are inadequate, obsolete, dilapidated and unsuitable for preparing competent teachers. This state of affairs raises concern about the quality of teachers from emerging private primary teacher training colleges serving in the school system. The reviewed literature indicates that provisions of adequate materials are significant to ensure learners acquire literacy and numeracy skills although none of the study has been conducted in Keiyo South Sub- County.

\section{Materials and Methods}

The research design for this study was descriptive survey. This study was carried out in Keiyo South Sub County in
Elgeyo Marakwet County of Rift Valley Province in Kenya. The target population involved all public 60 pre-primary schools in Keiyo South with a population of 144 teachers. The study used questionnaire in getting responses from teachers' perception on the influence of selected school factors on pre-school children competency skills. Data was collected using questionnaires with structured questions. Quantitative data from questionnaires was coded, entered and analysed with help of computer softwares (Statistical Package for Social Sciences [SPSS]). Quantitative data was analysed using descriptive statistics (frequencies and percentages). The output of analysed data is presented using frequency distribution tables, bar graphs.

\section{Results}

Teachers Perception on the Influence of Adequacy of Learning Resources on Acquisition of Competency Skills The first objective of the research was to determine preschool teachers' perceptions on the influence adequacy of learning resources towards learners' acquisition of competency skills in reading, writing and numeracy in preschool centres in Keiyo South Sub County. The results are presented in Table 2 .

Table 2: Pre-school Teachers' Perceptions on the Influence of Adequacy of Learning Resources on Acquisition of Competency Skills

\begin{tabular}{|c|c|c|c|c|c|c|c|c|c|c|}
\hline \multirow[t]{2}{*}{ Adequacy } & \multicolumn{2}{|c|}{$S D$} & \multicolumn{2}{|c|}{$D$} & \multicolumn{2}{|c|}{$U D$} & \multicolumn{2}{|r|}{$A$} & \multicolumn{2}{|c|}{$S A$} \\
\hline & $f$ & $\%$ & $f$ & $\%$ & $f$ & $\%$ & $f$ & $\%$ & $f$ & $\%$ \\
\hline $\begin{array}{l}\text { Adequacy of textbooks influence learners acquisition of competency } \\
\text { skills in reading, writing and numeracy }\end{array}$ & 1 & 1.3 & 6 & 8.0 & 2 & 2.7 & 34 & 45.3 & 32 & 42.7 \\
\hline $\begin{array}{l}\text { Adequacy of furniture influence pupils ability to write correctly } \\
\text { specified words and names }\end{array}$ & 4 & 5.3 & 7 & 9.3 & 1 & 1.3 & 30 & 40.0 & 33 & 44.0 \\
\hline Adequacy of sound charts influence learners acquisition of oral skills & 1 & 1.3 & 11 & 14.7 & 4 & 5.3 & 35 & 46.7 & 24 & 32.0 \\
\hline Adequacy of number charts influence pupils acquisition of number skills & 2 & 2.7 & 2 & 2.7 & 6 & 8.0 & 35 & 46.7 & 30 & 40.0 \\
\hline $\begin{array}{l}\text { Adequacy of storybooks with picture illustration influences learners } \\
\text { ability to develop their skills }\end{array}$ & 1 & 1.3 & 3 & 4.0 & 1 & 1.3 & 34 & 45.3 & 36 & 48.0 \\
\hline $\begin{array}{l}\text { Adequacy of pieces of chalks for teachers to use influence pupils ability } \\
\text { to improve their numeracy and writing skills }\end{array}$ & 1 & 1.3 & 5 & 6.7 & 2 & 2.7 & 41 & 54.7 & 26 & 34.7 \\
\hline $\begin{array}{l}\text { Adequacy of alphabetical charts influences pupils ability to improve } \\
\text { their writing and communication skills }\end{array}$ & 1 & 1.3 & 7 & 9.3 & 1 & 1.3 & 43 & 57.3 & 23 & 30.7 \\
\hline $\begin{array}{l}\text { Adequacy of plasticine/clay influence pupils capacity to improve their } \\
\text { creativity and modelling skills }\end{array}$ & 2 & 2.7 & 3 & 4.0 & 1 & 1.3 & 26 & 34.7 & 43 & 57.3 \\
\hline Mean perception & 2 & 2.2 & 6 & 7.3 & 2 & 3.0 & 35 & 46.3 & 31 & 41.2 \\
\hline
\end{tabular}

The results of the study from Table 2 shows that 34 (45.3\%) agreed and $32(42.7 \%)$ of teachers agreed that adequacy of textbooks for learning influences pre-school pupils acquisition of competency skills in reading, writing and numeracy. Only $6(8.0 \%)$ disagreed and $1(1.3 \%)$ strongly disagreed with the statement. This shows that teachers consider that if enough textbooks are provided, it will ensure that learners develop reading, writing and numeracy skills. Teachers appear to be supporting the statement. The findings coincide with Kamau (2010) who found out that there were very inadequate learning materials in those classes, with some classes having none at all in Makuyu and this affected learning. Similarly, Likoko et al., (2013) found out that basic instructional resources like teaching aids, stationary and textbooks were inadequate in teachers training college and this affected the competency of learners in Bungoma.
Result also showed that $30(40.0 \%)$ of teachers agreed and $33(40.0 \%)$ strongly agreed that adequacy of furniture influenced pupils ability to write correctly specified words and names. only, 4 (5.3\%) strongly disagreed and 7 (9.3\%) disagreed with the statement and this could be due to their school lacking enough furniture to support ECDE learning. However, majority $(80 \%)$ of teacher appear to coincide with the statement that adequacy of furniture influence pupils ability to write properly hence improving their hand writing, speed and also quality of writing in numbers and words. This happens whereby pre-school centres have enough tables, chairs and even desks to write on. Learners will develop their ability to hold pencils and crayons well when the writing surface is of quality. Moreover, lack of necessary facilities like tables and desk (top) will hinder children development of writing skills. The results agree with 


\section{International Journal of Science and Research (IJSR) \\ ISSN (Online): 2319-7064 \\ Index Copernicus Value (2013): 6.14 | Impact Factor (2015): 6.391}

Rotumoi and Too (2012) who observed that the availability and adequacy of classroom space, teaching/learning facilities and the number of children a teacher handled were also found to have had great influence on the teaching methods the teacher adopted. A research by Likoko et al., (2013) found out that quite a number of the colleges $61.9 \%$ had enough furniture, and (38.1\%) lacked enough furniture. In South Africa, O'Connor and Geiger (2009) found out that owing to their social circumstances not many learners had their own stationery and unless teachers provided out of their own pockets, they were unable to do creative activities with the learners. Teachers also needed bigger classrooms since classes were very crowded. It was also evident from 35 $(46.7 \%)$ of teachers who agreed and $24(32.0 \%)$ who strongly agreed that adequacy of sound charts influenced pupils acquisition of oral skills, $1(1.3 \%)$ strongly disagreed, $11(14.7 \%)$ disagreed and $4(5.3 \%)$ were undecided on the statement. This shows that teachers perceive that when sound charts are enough for children, they will develop their oral skills in communication. However, $16 \%$ of teachers who disagreed could be due to their unavailability of sound charts in their schools thereby not seeing their needs in assisting learners to improve on their oral skills. The results agrees with Kamau (2010) who found out that majority of the classes where were some, they were in form of charts, this affected learners mathematics skills. The provision of adequate charts in pre-school will help pre-school pupils to form mental images and hence facilitate proactive learning. In addition, children's work display initiates competition and appreciation of their own learning efforts as they manifest their competencies. Ogunbiyi (2004) also maintains that this concentration by the students on what is going on helps them to follow the lesson and learn whatever concepts are being explained. Such attention also helps teachers sense the readiness of students to understand what is being taught. When asked to indicate their perceptions on whether adequacy of numbered charts, 2 (2.7\%) strongly disagreed, 2 $(2.7 \%)$ disagreed, $6(8.0 \%)$ were undecided, 35 (46.7\%) agreed and $30(40.0 \%)$ strongly agreed that they influence pupils acquisition of number skills. Majority $86.7 \%$ of teachers perceive that when they are provided with the right quantity of numbered charts, their pupils will easily acquire number skills that are important for learning mathematics, when this materials are not availed in right quantity, there appears to be a problem in learners not developing critical mathematics skills at that tender age which is significant. Kamau (2010) concurs with this view by indicating that no better performance can be realized in mathematics performance in lower primary schools in Makuyu zone due to lack of involvement of many senses (through manipulation of learning resources) during learning. In addition, Mbugua (2011) found out that teaching and learning aids contribute to achievement in mathematics. However, there are insufficient mathematics text books in secondary schools. It was also seen that $36(48.0 \%)$ of teachers strongly agreed and $34(45.3 \%)$ agreed that adequacy of storybooks with picture illustration influenced pupils ability to develop their skills. Only $1(1.3 \%)$ strongly disagreed, $3(4.0 \%)$ disagreed and $1(1.3 \%)$ was undecided. This shows that when enough storybooks are provided, learners will develop reading skill, problem solving skills, creative and imaginary skills and also vocabulary. Moreover, when storybooks are provided, some present ideas to pupils on culture, animals and also issues that affect people in daily living. Eshiwani (1984) supports this view by suggesting that for effective teaching and learning, textbooks and resource materials are basic tools, in absence or inadequacy makes teachers handle subjects in an abstract manner, portraying it a dry and non-exciting. Most $41(54.7 \%)$ of teachers agreed while $26(34.7 \%)$ strongly agreed that when chalks are adequate, they will help teachers to write in chalkboards making learners to copy and see what their teachers are telling them through the word of mouth. However, a small proportion $1(1.3 \%)$ strongly disagreed, 5 $(6.7 \%)$ disagreed and $2(2.7 \%)$ were undecided. this shows that majority of teachers prefer to have adequate boxes of chalks to enable effective instruction in classrooms. This could be due to the fact that majority of ECDE centres lack adequate classroom resources and this could affect the effective implementation of curriculum. The chalks are used to make illustrations in the board so that learners can copy what their teacher is writing at the front. Learners can also avoid common mistakes in spelling when the information they are supposed to learn is written well in the chalk board. The study coincides with Kadzera (2006) in Malawi whose results of the analysis showed that there was more use of the chalkboard than flip charts, overhead projectors, videos and computers. Furthermore, some of the tutors did not use the local resources to develop instructional aids. Tutors reported that it took too much time to make such learning materials. Findings also revealed that most $43(57.3 \%)$ of teachers agreed and $23(30.7 \%)$ strongly agreed that adequacy of alphabetical charts in classroom influenced pre-school pupils ability to improve their writing and communication skills. But, $7(9.3 \%)$ of the teachers disagreed, 1 (1.3\%) strongly disagreed and $1(1.3 \%)$ was uncertain. The results suggest that majority of teachers $(88.0 \%)$ consider that provision of sufficient alphabetical charts will help learners to improve on their skills in knowing the sequence of alphabets and also animals or objects associated with specific letters. Ogunbiyi (2004) adds that these resources also helps pupils to associate with in their daily life situations which also help to generate that desire to do more hence leading to acquisition of relevant numeracy and literacy skills. Language gives young children the power to question and find answers. On whether the sufficiency of plasticine or clay materials influenced pupils capacity to improve their creative and modelling skills, $2(2.7 \%)$ strongly disagreed, $3(4.0 \%)$ disagreed, 1 (1.3\%) was undecided, 26 (34.7\%) agreed and $43(57.3 \%)$ strongly agreed with the statement. This implies that clay materials are important for learners to learn creative activities in moulding of pots, animals among other items. The teachers seem to agree with this statement bearing the fact that most areas have anthills while others have clay soil that facilitate moulding as opposed to plasticine that is rarely available and costly to purchase by public ECDE centres. In general, $2(2.2 \%)$ of teachers strongly disagreed, $6(7.3 \%)$ disagreed, $2(3.0 \%)$ were undecided, 35 (46.3\%) agreed and $31(41.2 \%)$ strongly agreed on the adequacy of instructional resources in influencing pre-school pupils acquisition of competency skills. This shows that most $87.3 \%$ perceive that adequacy of instructional resources in classroom is critical for learners to achieve specific competencies in numeric, writing and even reading. However, some teachers perceived that inadequacy and unavailability of instructional resources could influence learners' capacity to acquire numeracy and 


\section{International Journal of Science and Research (IJSR) \\ ISSN (Online): 2319-7064 \\ Index Copernicus Value (2013): 6.14 | Impact Factor (2015): 6.391}

literacy skills. The findings are similar to what Ndani and Kimani (2010) who found out that in $55 \%$ of the preschools, the physical environment was below average in suitability thereby affecting learners acquisition of critical competencies. The findings agree with those of Vos (2004) who indicated that inadequate facilities could have harmful effect on the quality of education. The availability of equipment and the supply of teaching/learning materials also contributed to teachers' satisfaction with the physical environment.
Pre-school Teachers' Perceptions on the Influence of Appropriateness of Learning Resources on Pupils' Competency Skills

The second objective of the study was to determine preschool teachers' views on the influence of appropriateness of learning resources on pre-school children acquisition of competency skills. Therefore, the teachers were asked to state how appropriateness of learning resources influenced pupils acquisition of reading, literacy and numeracy skills. The findings are given in Table 3.

Table 3: Pre-school Teachers' Perceptions on the Influence of Appropriateness of Learning Resources on Pupils' Competency Skills

\begin{tabular}{|c|c|c|c|c|c|c|c|c|c|c|}
\hline \multirow[t]{2}{*}{ Appropriateness of learning resources } & \multicolumn{2}{|c|}{ SD } & \multicolumn{2}{|c|}{ D } & \multicolumn{2}{|c|}{ UD } & \multicolumn{2}{|c|}{$\mathbf{A}$} & \multicolumn{2}{|c|}{ SA } \\
\hline & f & $\%$ & f & $\%$ & f & $\%$ & f & $\%$ & f & $\%$ \\
\hline $\begin{array}{l}\text { Appropriateness of print educational medial resources influence pre-school } \\
\text { pupil acquisition of reading skills }\end{array}$ & 1 & 1.3 & 3 & 4.0 & 7 & 9.3 & 51 & 68.0 & 13 & 17.3 \\
\hline $\begin{array}{l}\text { Appropriateness of mathematical shapes influence preschool pupils develop } \\
\text { their drawing and art skills }\end{array}$ & 2 & 2.7 & 5 & 6.7 & 3 & 4.0 & 37 & 49.3 & 28 & 37.3 \\
\hline $\begin{array}{l}\text { Appropriateness of radio media influence pupils capacity to communicate } \\
\text { and spell words correctly }\end{array}$ & 12 & 16.0 & 6 & 8.0 & 6 & 8.0 & 32 & 42.7 & 19 & 25.3 \\
\hline $\begin{array}{l}\text { Appropriateness of play materials for learning influence on learners } \\
\text { development of psychomotor skills thereby improving their health and } \\
\text { making them healthy }\end{array}$ & 1 & 1.3 & 3 & 4.0 & 1 & 1.3 & 23 & 30.7 & 47 & 62.7 \\
\hline $\begin{array}{l}\text { Appropriateness of mathematical models for learning influence pupils } \\
\text { ability to develop their numerical skills }\end{array}$ & 0 & 0.0 & 2 & 2.7 & 4 & 5.3 & 40 & 53.3 & 29 & 38.7 \\
\hline $\begin{array}{l}\text { Appropriateness of mathematical quizzes in classroom instruction influence } \\
\text { learners to develop logical and computation skills }\end{array}$ & 1 & 1.3 & 3 & 4.0 & 4 & 5.3 & 37 & 49.3 & 30 & 40.0 \\
\hline Teachers perception & 3 & 3.8 & 4 & 4.9 & 4 & 5.5 & 37 & 48.9 & 28 & 36.9 \\
\hline
\end{tabular}

Table 3 result shows that most $51(68.0 \%)$ of pre-school teachers agreed and $13(17.3 \%)$ strongly agreed that appropriateness of print media instructional resources enhances acquisition of reading skills by learners. Only 3 $(4.0 \%)$ disagreed, $1(1.3 \%)$ strongly agreed with the statement while $7(9.3 \%)$ were undecided. This shows that when school purchase and ensure that teachers use appropriate print media resources, teachers perceive them to be critical towards ensuring learners develop reading skills in pre-school centres as perceived by their teachers. However, Ogunbiyi (2004) contradicts this view by indicating that availability of instructional materials does not automatically mean that learning will take place. In addition to availability, learning also depends on the situation, the teacher, her/ (his) energy, her / (his) imagination (and creativity), and those thirty or more unique personalities. On the statement that appropriateness of mathematical shapes influence preschool pupils develop their drawing and art skills, 2 (2.7\%) strongly disagreed, 5 (6.7\%) disagreed, 3 (4.0\%) were undecided, 37 (49.3\%) agreed while 28 (37.3\%) strongly agreed. This implies that suitability and aptness of mathematical shapes for use by teachers when teaching in pre-school will aid learners to develop drawing and art skills. This indicates that majority of teachers value the appropriateness of mathematical shapes in classroom learning which will enable pre-school pupils' capacity to develop numeracy skills. Similar to the study findings, Mbugua (2011) established that schools have poor chalk boards which affect teaching and learning of mathematics, since the subject involves a lot of calculations, which has to be on the chalk board. Three dimension models or aids for teaching and learning mathematics are lacking, those that are available are of poor quality, and also teachers do not use them effectively well.The findings of the study further showed that $12(16.0 \%)$ strongly disagreed and $6(8.0 \%)$ of pre-school teachers disagreed with the statement that appropriateness of radio media influence pupils capacity to communicate and spell words correctly availability of radio enhances pupils ability to communicate and spell the words correctly, 6 (8.0\%) were undecided, 32 (42.7\%) agreed and $19(25.3 \%)$ strongly agreed. It is seen that more than $60 \%$ of pre-school teachers supported this statement although a significant $24.0 \%$ were against the statement; they could be teachers who earlier had indicated that they did not have radios in their schools. The result showed that teachers approve that appropriateness of radio media will improve learners' literary skills. The study also found out that 23 $(30.7 \%)$ of respondents agreed and majority 47 (62.7.0\%) strongly agreed that appropriateness of play materials for learning influence on learners development of psychomotor skills thereby improving their health and making them healthy. $1(1.3 \%)$ strongly disagreed, $3(4.0 \%)$ disagreed while $1(1.3 \%)$ were undecided. Almost all $93.4 \%$ of respondents supported this statement. When these materials are available, learners have an opportunity of practicing outdoor games and this not only improves their psychomotor skills, they also become active and healthy. The finding implies sufficient sports kits for play influences pupils acquisition of psychomotor skills. The study results are in line with Rotumoi and Too (2012) who found out that Availability and appropriateness of play facilities was crucial as it determined children's socialization, coverage of activity areas and development of psychomotor skills. Results of the study showed that only $2(2.7 \%)$ of teachers disagreed and $4(5.3 \%)$ were undecided on the statement that appropriateness of mathematical models for learning 


\section{International Journal of Science and Research (IJSR) \\ ISSN (Online): 2319-7064}

Index Copernicus Value (2013): 6.14 | Impact Factor (2015): 6.391

influence pupils ability to develop their numerical skills. Most 40 (53.3\%) agreed and $29(38.7 \%)$ strongly agreed with the statement. This shows that suitability of mathematical shapes have great influence on pre-school pupils capability to acquire mathematical skills important for their development. The result also suggests that teachers value most the appropriateness of mathematical shapes in improving numerical skills by pupils. Lastly, when asked about the appropriateness of mathematical quizzes in classroom instruction on whether it influenced learners to develop logical and computational skills, 1 (1.3\%) strongly disagreed, $3(4.0 \%)$ disagreed, $4(5.3 \%)$ were undecided, close to half $37(49.3 \%)$ agreed while $30(40.0 \%)$ strongly agreed with the statement. This shows that teachers need to source for correct mathematical quizzes that will enable the pupils to develop logical and computation skills. To compute average scores for pre-school teachers perceptions on the appropriateness of learning resources in aiding preschool learners competencies, scores strongly disagree and disagree were combined labeled not appropriate and also the same was done for agree and strongly agree were labelled as appropriate, the undecided scores remained unchanged and were labeled as moderately appropriate. The summary of the computation made are given in Table 4.

Table 4: Teachers' Perceptions on the Appropriateness of Learning Resources in Enhancing Pupils Competency Skills

\begin{tabular}{|l|c|c|}
\hline Perceptions & Freq & Percent \\
\hline Not appropriate & 7 & 8.7 \\
\hline Moderately appropriate & 4 & 5.5 \\
\hline Appropriate & 64 & 85.8 \\
\hline Total & $\mathbf{7 5}$ & $\mathbf{1 0 0 . 0}$ \\
\hline
\end{tabular}

Table 4 result shows that most $64(85.5 \%)$ of pre-school teachers said that the learning resources in their classrooms were appropriate in enhancing pre-school learners acquisition of competency skills. The table further show that $4(5.5 \%)$ said that the learning resources were moderately appropriate while $7(8.7 \%)$ said the learning resources were inappropriate. This finding implies that for learners to acquire numeracy, literacy and reading skills, the resources used by their teachers should be appropriate. This underscores the significance of ensuring that right resources are provided to learners in schools. The findings concur with Ogunbiyi (2004) research in Nigeria who found out that in pre-school centres where resources were supplied for instructional use, teachers were expected to make use of them to support a smooth and meaningful flow of instruction and, consequently promoting the understanding of the content being taught by pre-school pupils. Therefore, in a school learning resources can be available, but if they are inappropriately used the students may not benefit from their use. Similarly the learning resources can be available, but, if the tutors do not know how to use them, then learning that could have been enhanced by the use of the technologies will not occur. Likoko et al., (2013) found out that the status of instructional materials, equipment and facilities are inadequate, obsolete, dilapidated and unsuitable for preparing competent teachers and this could affect their usage in classrooms as they were not taught using appropriate resources.

\section{Conclusions and Recommendations}

Availability and adequacy of instructional resources and facilities will aid learners' acquisition of different competencies in pre-school centres. When resources are scarce or unavailable, learners will not develop required competencies in early childhood education in Keiyo South Sub County. It was established that $85.8 \%$ of teachers agreed that appropriateness of learning resources was critical to pre-school pupils' acquisition of competencies. Teachers perceived that learning resources and materials used for learning must be appropriate, relevant and beneficial to preschool pupils. When teachers select and utilise better learning resources, pre-school pupils' competency is enhanced and this makes them to acquire reading, writing and even counting skills. To address inadequate teaching and learning resources in classrooms, the study suggests that there is need for all stakeholders to come on board and support pre-school centres that are under community and public primary schools. This will ensure that required resources are available and learners will benefit from them by developing competencies in numeric, literary and oral skills. To address teacher appropriateness of instructional materials, there is need for head teachers to supervise and direct teachers to select and use appropriate instructional materials that will better learners' acquisition of competency skills.

\section{References}

[1] Adeogun, A.A. (2001). The principal and the financial management of public secondary schools in Osun State. Journal of Educational System and Development, 5(1), $1-10$.

[2] Akungu, J.A. (2014). Influence of teaching and learning resources on students' performance in Kenya certificate of secondary education in free day secondary Education in Embakasi district, Kenya. MED Research Project, University of Nairobi.

[3] Barasa, B. L. (2005). English language Teaching in Kenya: Policy, Training and Practice. Eldoret: Moi University Press.

[4] Baylor, A.L. \& Ritchie, D. (2002). What factors facilitate teacher skill, teacher morale, and perceived student learning in technology using classrooms? Computer and Education, 39, 395-414

[5] Blakemore, S., \& U. Frith. (2005). The learning brain. Oxford: Blackwell.

[6] Bunyi, G.W. Wangia, J. Magoma, C. M. \& Limboro, C. M. (2011). Learning to Teach Reading and Mathematics and Influences on Practice: A Study of Teacher Education in Kenya. Kenyatta University \& Kwame Akyeampong - University of Sussex.

[7] Charles, C.M. \& Senter, G.W. (2002). Elementary classroom management (3rd Ed.). Boston: Allyn \& Bacon.

[8] Corsaro, W.A. \& Molinari, L. (2005). Campaign: Understanding Children's transition from Preschool to Elementary School. New York: Teachers College Press.

[9] Docket, S. \& Perry, B. (2001). Starting school. Effective transition. Early childhood Research and Practice. Retrieved from http://ecrp.uiuc.edu/v3n2/docket.html. 


\section{International Journal of Science and Research (IJSR) \\ ISSN (Online): 2319-7064 \\ Index Copernicus Value (2013): 6.14 | Impact Factor (2015): 6.391}

[10] Du Plessis, S. \& Naude, E.C. (2003). The needs of teachers in preschool centres with regard to multilingual learners. South African Journal of Education, 23, 122129.

[11] Gogo, K.S. (2002). "Input of cost sharing on access, equity and quality of secondary education in Rachuonyo District". Unpublished ME.d. Thesis, Kenyatta University.

[12]Kadzera, C.M. (2006). Use of Instructional Technologies in Teacher Training Colleges in Malawi. D. Phil Dissertation, Virginia Polytechnic Institute and State University.

[13] Kamau, B. (2010). Impact of the Pre-School Programme on Mathematics Performance in Lower Primary Schools of the Makuyu Zone, Murang'a South District. Unpublished MED Project, University of Nairobi.

[14] Kenya Institute of Education (2008). Early childhood development and education syllabus. Nairobi: Kenya Institute of Education.

[15]Likoko, S., Mutsotso, S. \& Nasongo, J. (2013). The Adequacy of Instructional Materials and Physical Facilities and their Effects on Quality of Teacher Preparation in Emerging Private Primary Teacher Training Colleges in Bungoma County, Kenya. International Journal of Science and Research (IJSR), 2 (1), 403-408.

[16] Mbugua, Z. K. (2011). Adequacy And The Extent To Which Teaching And Learning Resources For Mathematics Are Available And Used For Achievement In The Subject In Secondary School In Kenya. American International Journal of Contemporary Research, 1 (3), 112-116.

[17] Murundu Z. O., Chisikwa, I. F. \& Okwara, M. O. (2010). School based factors influencing implementation of early childhood development and education curriculum. Educational Research, 1(9), 382389.

[18] Mweru, M. (n.d). Teachers' Influence on Children's Selection and Use Of Play Materials In Kenya. Sustainable Programs for Reducing Educational and Avocational Disadvantages.

[19] National Curriculum Research (2007). Parental involvement: Its contribution to high school students' motivation. The Clearing House, 75(3), 132-134.

[20] Ngaruiya, S. (2004). Assessing the Influence of Different Early Childhood Development Models on Pre-School Children's School Readiness in Kenya. M.A. Thesis, University of Victoria.

[21] O’Connor, J. \& Geiger, M. (2009). Challenges facing primary school educators of English Second (or Other) Language learners in the Western Cape. S. Afr. J. Educ, 29 (2), 16-29.

[22] Ogunbiyi, O. (2004). New challenges in the methodologies of Teaching, A case of in-service programme for school teachers in Elaturoti, F and Babarinde K (eds) Teachers' Mandate on Education and Social Development in Nigeria.

[23] Ou, S., \& Reynolds, A.J. (2004). Preschool education and school completion. In Encyclopedia on early childhood development, eds. R.E. Tremblay and R. De V. Peters. Montreal, Quebec: Centre of Excellence for Early Childhood Development.
http://excellenceearlychildhood.ca/documents/OuReynoldsANGxp.pdf (accessed December 9, 2015).

[24] Rotumoi, J. \& Too, J. K. (2012). Factors Influencing the Choice of Approaches Used By Pre-School Teachers in Baringo County, Kenya. International Journal of Academic Research in Progressive Education and Development, 1(2), 177-187.

[25] Schonwetter, D. J. (2008). "The teaching resource portfolio", In Robertson, D.R and Nilison, B.L (Eds). To improve the academy; Resources for faculty, instructional, and organizational Development. San Francisco: John Wiley and sons, Inc.

[26] Shonkoff, J.P., \& D. Phillips. (2000). From neurons to neighbourhoods: The science of early child development. Washington, DC: National Academy Press.

[27]UNESCO (2005). Policy Review Report: Early Childhood Care and Education in Kenya. UNESCO: Paris.

[28] UNESCO. (2007). Education for all global monitoring report*strong foundations: Early childhood care and education. Paris: UNESCO. 